Rakenteiden Mekaniikka (Journal of Structural Mechanics)

Vol. 50, No 3, 2017, pp. $182-185$

https://rakenteidenmekaniikka.journal.fi/index

https://doi.org/10.23998/rm.64743

(c) The author(s) 2017.

Open access under CC BY-SA 4.0 license.

\title{
Thermomechanical fatigue analysis of cylinder head
}

Anton Leppänen ${ }^{1}$, Asko Kumpula, Joona Vaara, Massimo Cattarinussi, Juho Könnö and Tero Frondelius

Summary. The finite element simulation of a cylinder head has been carried out with Abaqus Standard using Z-mat material model, with thermal boundary conditions coming from combined conjugate heat transfer and gas-exchange simulations. The fatigue post-processing of results has been done with Z-post software using ONERA fatigue model. The resulting lifetime values have been found out to correspond well to observations from the field.

Key words: fatigue, thermomechanical fatigue, cylinder head, ONERA, FEM, CFD, Wärtsilä

Received 13 June 2017. Accepted 7 August 2017. Published online 21 August 2017.

\section{Introduction}

Thermomechanical fatigue analysis is a method to estimate the component lifetime by considering the combined thermal and mechanical loading. In this paper, the method application for the cast iron cylinder head component is presented, considering the varying material properties caused by the casting process. This assessment is done by first simulating the stress and strain caused by thermal and mechanical loading with Abaqus finite element simulation and then performing the fatigue post-processing of the results for the component lifetime estimation. The result is the lifetime estimate for the cylinder head and location of critical points.

\section{Simulation workflow}

The simulation is performed for an assembly which includes all the main components connected to the cylinder head. The main loading conditions are the assembly loads, thermal load, and cylinder pressure load. The engine operating profile is taken into account, mainly the number of starts and stops and the number of engine cycles per day. Component temperatures are simulated with Star-CCM+ software [7], where both the thermal load from combustion and the cooling water flow are solved simultaneously [10]. The contact interfaces between the components are modeled as frictional contacts, considering the shrink fits and clearances [13].

\footnotetext{
${ }^{1}$ Corresponding author. anton.leppanen@wartsila.com
} 
The simulated cylinder head is made of nodular cast iron material, which has spatially varying material properties caused by the casting process. For that reason the local material micro structure is considered in the analysis. This is done for both the material mechanical response and the fatigue analysis. The material parameters for each micro structure have been defined based on cyclic material tests performed with various loading conditions.

The component stress and strain are simulated with Abaqus Standard solver [6] using the Z-mat material library for non-linear material behavior. The Z-mat model is working as Abaqus subroutine, calculating the mechanical response during simulation. Unified Chaboche viscoplasticity constitutive model is used for modeling the material inelastic behavior [5]. The material model includes the effects of thermal dependency and cyclic plasticity, including kinematic and isotropic hardening, creep and stress relaxation $[1,2]$. Used plasticity criterion is:

$$
f=J(\boldsymbol{\sigma}-\boldsymbol{X})-Y \leq 0,
$$

where $J$ is the Von Mises distance in the deviatoric stress space, $\boldsymbol{X}$ is the back stress tensor and $Y$ is the yield stress. Multiple engine cycles are simulated to achieve a stabilized solution (Figure 1).

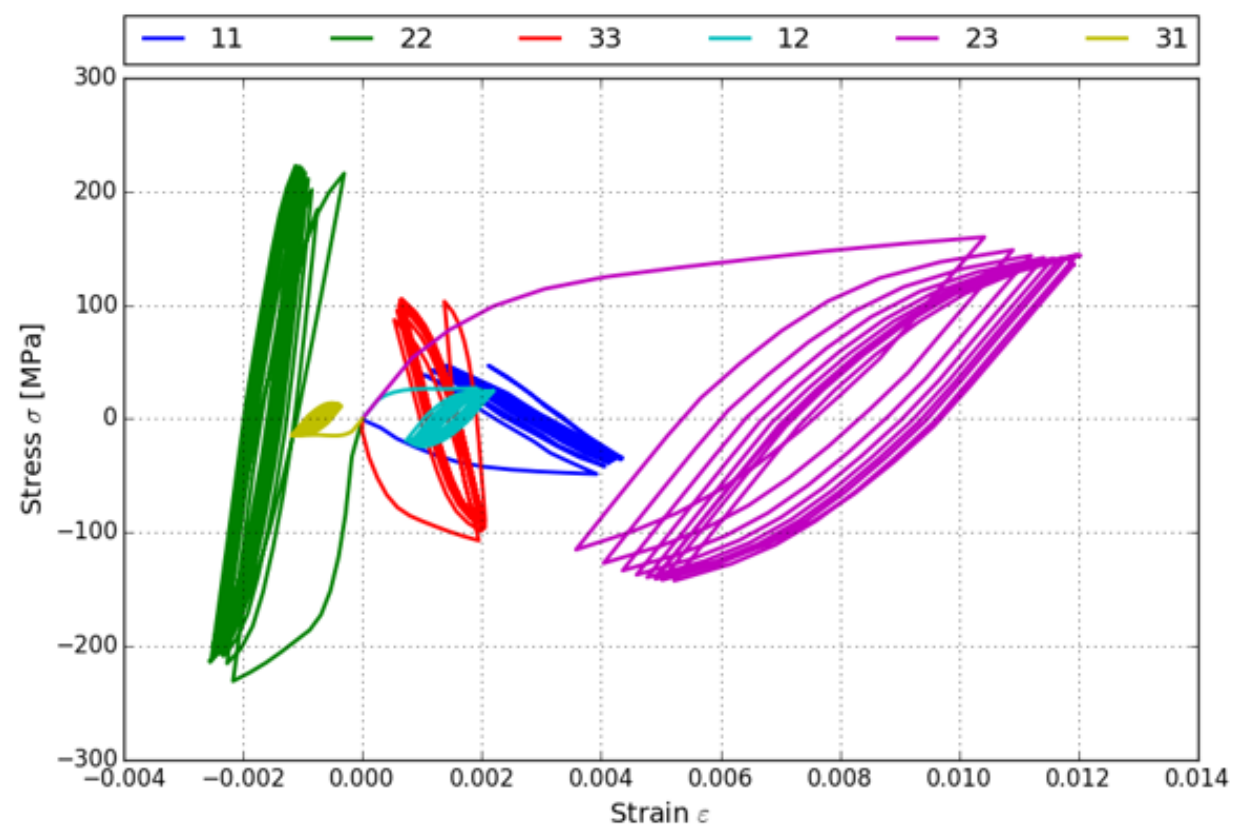

Figure 1. Componentwise stress-strain evolution during simulation in one material point. The point is located between cylinder head exhaust and intake channels.

The lifetime estimation is made by post-processing the FE results with the Z-post software with ONERA fatigue damage model [4, 12]. The fatigue model considers nonlinear accumulation of damage, taking into account the full stress-strain history. The temperature effect, local material microstructure, mean stress effect, stress multiaxiality and engine operating profile are included in the analysis. ONERA fatigue model and used material parameters are presented in more detail in [9]. The result from the fatigue analysis is a lifetime estimation for each point in the cylinder head. By post-processing the results, the most critical locations are found with the corresponding lifetime estimation (Figure 2). 


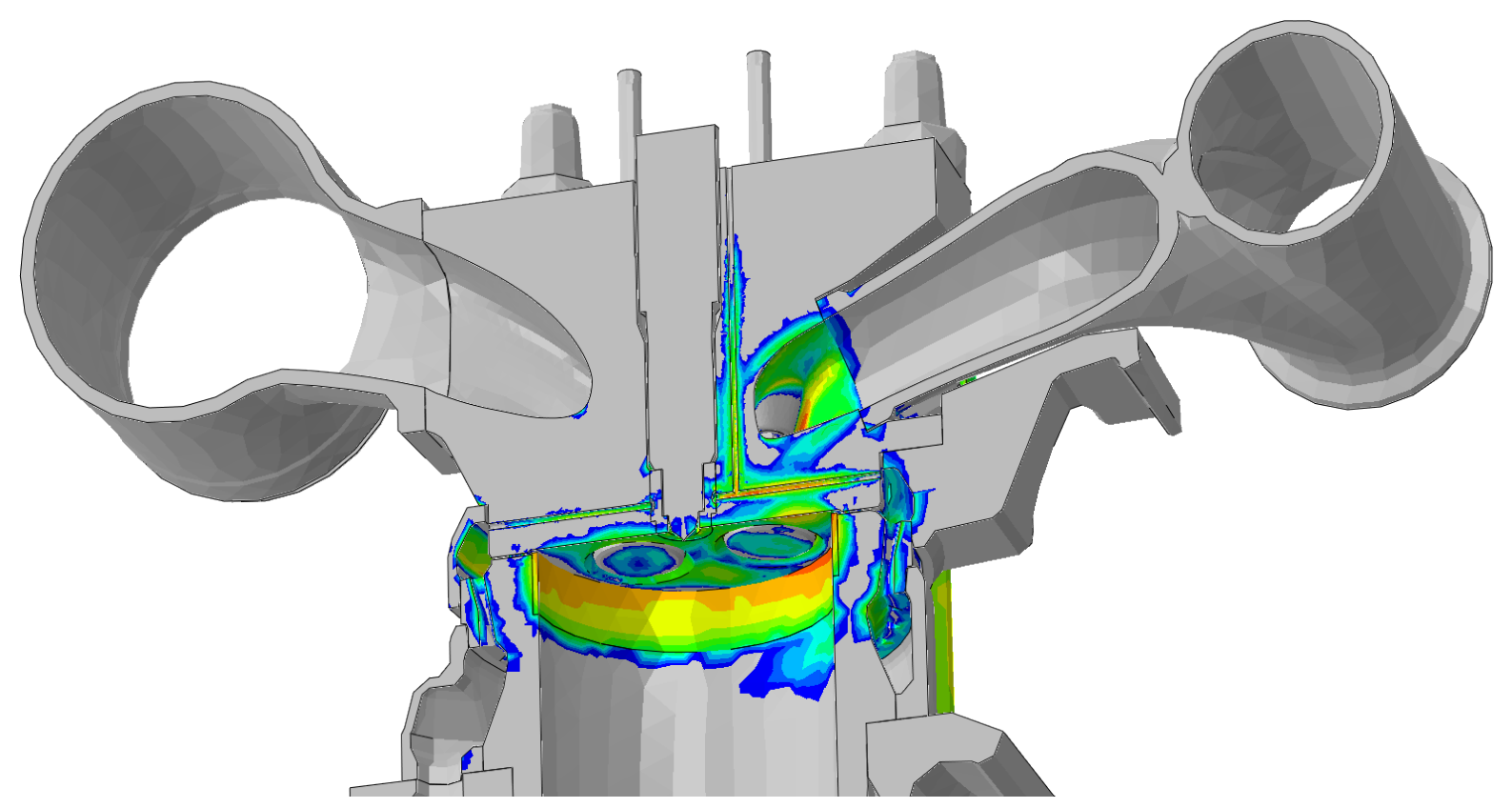

Figure 2. Cylinder head fatigue lifetime

When the critical locations are known, a fracture-mechanics-based crack growth analysis can be performed to ensure the safety of the component in the case of possible crack initiation [11].

The calculated critical locations have been found to correlate well with the real-life component critical locations. Also the calculated lifetime estimations have corresponded reasonably well to the actual component lifetime in the field.

\section{Conclusions}

The thermomechanical fatigue analysis has proven to be a good way to achieve reliable lifetime estimation results for the cylinder head. By using this methodology, it is possible to find out the possible critical locations, identify reasons for failures in the existing components and make design changes to achieve better component lifetime. Finally, the analysis can be simplified in such a way that it is possible to achieve reasonably accurate results in a shorter time for a quick concept phase design $[3,8]$.

\section{References}

[1] Farida Azzouz, Georges Cailletaud, Ronald Foerch, Guillaume Morin, Stéphane Quilici, and Patrick Ragot. Identification of viscoplastic constitutive and creepfatigue damage coefficients to use in abaqus automotive structural calculations with the zmat library. In ABAQUS Users Conference, pages 1-15, 2002.

[2] Jacques Besson, Georges Cailletaud, Jean-Louis Chaboche, and Samuel Forest. Nonlinear mechanics of materials, volume 167. Springer Science \& Business Media, 2009.

[3] Massimo Cattarinussi, Anton Leppänen, Juho Könnö, and Tero Frondelius. Cylinder head design of experiment by using the wärtsila digital design platform. Rakenteiden Mekaniikka, 50(3):330-332, 2017. URL https://doi.org/10.23998/rm.64923. 
[4] J. L. Chaboche and P. M. Lesne. A non-linear continuous fatigue damage model. Fatigue $\&$ Fracture of Engineering Materials \& Structures, 11(1):1-17, 1988. ISSN 1460-2695. URL https://doi.org/10.1111/j.1460-2695.1988.tb01216.x.

[5] J.L Chaboche. Unified cyclic viscoplastic constitutive equations: Development, capabilities, and thermodynamic framework. In Unified constitutive laws of plastic deformation. Elsevier, 1996.

[6] Dassault Systemes Simulia Corp. Abaqus theory guide. 2017.

[7] STAR-CCM+ User Guide. version 10.02, 2015.

[8] Juho Könnö, Hannu Tienhaara, and Tero Frondelius. Wärtsilä digital design platform. Rakenteiden Mekaniikka, 50(3):234-238, 2017. URL https://doi.org/10. $23998 / \mathrm{rm} .64621$.

[9] Asko Kumpula, Joona Vaara, Anton Leppänen, and Tero Frondelius. Nodular cast iron ONERA fatigue model fitting. Rakenteiden Mekaniikka, 50(3):179-181, 2017. URL https://doi.org/10.23998/rm.64740.

[10] Aleksel̆ Vasil'evich Lykov. Heat and mass transfer. Mir Publishers, 1980.

[11] Joona Vaara, Antti Mäntylä, and Tero Frondelius. Brief review on high-cycle fatigue with focus on non-metallic inclusions and forming. Rakenteiden Mekaniikka, 50(3): 146-152, 2017. URL https://doi.org/10.23998/rm.65048.

[12] Miikka Väntänen, Joona Vaara, Jukka Aho, Jukka Kemppainen, and Tero Frondelius. Bayesian sequential experimental design for fatigue tests. Rakenteiden Mekaniikka, 50(3):201-205, 2017. URL https://doi.org/10.23998/rm.64924.

[13] Antti-Jussi Vuotikka, Mikael Nyberg, Heikki Karhinen, and Tero Frondelius. Contact sealing simulation of high pressured diesel injector. Rakenteiden Mekaniikka, 50(3): 313-317, 2017. URL https://doi.org/10.23998/rm.65060.

Anton Leppänen, Asko Kumpula, Joona Vaara, Juho Könnö and Tero Frondelius Wärtsilä

Järvikatu 2-4

65100 Vaasa

anton.leppanen@wartsila.com, asko.kumpula@wartsila.com, joona.vaara@wartsila.com, juho.konno@wartsila.com, tero.frondelius@wartsila.com

Massimo Cattarinussi

Wärtsilä Italy S.p.A.

Bagnoli della Rosandra, 334

34018 S. Dorligo della Valle, TS

Italy

massimo.cattarinussi@wartsila.com 